\title{
RELEASE OF METHANE AND CARBON DIOXIDE GASSES FROM MUNICIPAL SOLID WASTE LAND FILLS IN THE COLOMBO METROPOLITAN REGION.
}

\author{
S M Sandya Ramya Kumari and N J G J Bandara \\ Department of Forestry and Environmental Science, \\ University of Sri Jayewardenepura
}

Environmental and social problems caused from improper solid waste disposal are some . of the biggest environmental threats Sri Lanka face at present. Most of the waste generated in Sri Lanka ends up directly on open disposal sites on land. These disposal sites are overloaded and uncontrolled. Often the sites selected are marshy areas on lowland. These open dumps have posed serious environmental and social threats. Air pollution from landfill emissions ground water pollution from leachates health problems due to breeding disease causing pests and social problems such as decreasing land values and aesthetic appeal of an area etc. are some of these problems.

Currently about 60 temporary open dumpsites are in operation within the Colombo Metropolitan Region (CMR) alone. All of them can be said to be temporary because they are small in size, unplanned and unengineered. As in most other low and middle income countries Sri Lanka has a high percentage of organic content in their waste due to this high percentage of organic waste (80-90) high amounts of Carbon Dioxide and Methane are released in to the atmosphere from anaerobic degradation under low oxygen conditions prevalent in uncontrolled landfills. Thus in addition to many other social and environmental problems, Green house gas contribution is another major concern arising from the current waste disposal practices in Sri Lanka. It has been estimated that throughout the world about $8 \%$ of methane that is released in to the atmosphere comes from landfills

It is the intention of this study to estimate theoretically the amount of Green House Gases that is Carbon dioxide and Meth.une that is released into the atmosphere annually from the land fills operating in the Colombo Metropolitan Region. Most of the landfills are open dumpsites. Colombo, Gampaha and Kaluthara districts are located this region and 45 local authorities are included. All the relevant data was collected from each local authority in CMR by using questionnaire, primary interviews, and field observations and past data. Scholl canyon model was used to estimate Green House Gas emissions from the municipal solid waste

As model inputs the amount of waste dumped annually, the age of the land filled gas generation potential was used. Gas generational potential was calculated on the basis of the composition of waste. It is found that a substantial amount of green house gases Methane and Carbon Dioxide are released annually from the municipal solid waste dumps operating in the Colombo Metropolitan region.

Procedings of the Ninth Annual Forestry and Environment Sympasium 2003 of the Department of Forestry and Environmental Science, University of Sri Jayewardenepura, Sri Lanka 